\title{
SCANNING ELECTRON-MICROSCOPE ANALYSIS OF AEROSOLS IN SNOW AND ICE CORES FROM GREENLAND \\ (Abstract)
}

by

Motoi Kumai

(Cold Regions Research and Engineering Laboratory, 72 Lyme Road, Hanover, NH 03755, U.S.A.)

and

C.C. Langway, Jr

(Department of Geological Sciences, State University of New York at Buffalo, 4240 Ridge Lea Road, Amherst, NY 14226, U.S.A.)

\section{ABSTRACT}

In previous work, particle analyses of fresh snow and ice cores from Camp Century, Greenland, were conducted by transmission electron-microscopy. The particles found most frequently were silicate minerals $0.05-8 \mu \mathrm{m}$ diameter (Kumai 1977). The mean pH of snow in Ellesmere Island $\left(81^{\circ} \mathrm{N}, 73^{\circ} \mathrm{W}\right.$ ) was 5.23 for $1954-80$ (Koerner and Fisher 1982). The mean pH of snow in Hanover, $\mathrm{NH}$, was 4.61 for 1972-73 and 4.48 for 1980-83. The mean $\mathrm{pH}$ of snow in a rural area near Fairbanks, Alaska, was 5.60 for 1972-73 (Kumai 1985).

In this paper, the results of measurement of $\mathrm{pH}$, electrolytic conductivity, aerosol concentration and elemental analysis of aerosols in snow and ice cores from Greenland are described and compared with those of snow from Alaska, the Canadian Arctic and New Hampshire.

The snow samples were collected at Dye 3, Greenland, from 17 to $250 \mathrm{~cm}$ depth; they were deposited during snowfalls from January 1980 to spring 1983. A total of 45 snow samples was examined; the samples were each about $65 \mathrm{~g}$ and collected at $5 \mathrm{~cm}$ intervals in the snow pit. The snow and ice-core samples were melted in a microwave oven for measurements of $\mathrm{pH}$ and electrolytic conductivity. A pH meter (Solution Analyzer, model 4505A) was calibrated by two buffer solutions of $\mathrm{pH} 4.00$ and 7.00 at $25^{\circ} \mathrm{C}$. Two instruments were used for electrolytic conductivity measurements, Solution Analyzer, model 4505A, and Conductance Bridge RCM 1581, and calibrated by a standard solution of $0.005 \mathrm{~N} \mathrm{KCl}\left(720 \pm 1 \mu \mathrm{S} \mathrm{cm}^{-1}\right)$ at $25^{\circ} \mathrm{C}$. The snow and ice melt-water samples were filtered through polycarbonate membrane filters of $0.4 \mu \mathrm{m}$ pore diameter. Particles remaining on the filters dried in a vacuum oven at $30^{\circ} \mathrm{C}$, and the aerosol concentrations measured by chemical balance. The aerosols on the filters were coated by $\mathrm{Au}$ and $\mathrm{Pd}$ vapor in a vacuum chamber, for examination by scanning electron-microscopy and energy-dispersive X-ray analysis.
Results of melted snow measurements from Greenland were as follows. The $\mathrm{pH}$ ranged from 4.57 to 5.01 ; the mean $\mathrm{pH}$ was 4.81 in 1981 . For 1982 the $\mathrm{pH}$ ranged from 4.72 to 4.93 ; the mean was 4.81 . For 1983 , the $\mathrm{pH}$ ranged from 4.50 to 5.20 ; the mean was 4.85 . The mean $\mathrm{pH}$ of all snow from Greenland was lower than that of snow in a rural area of the Alaskan and Canadian Arctic, but higher than that of snow in New Hampshire.

Electrolytic conductivity of snow from Greenland varied from 3.95 to $9.70 \mu \mathrm{S} \mathrm{cm}^{-1}$ for 1981 , and the mean was $6.20 \mu \mathrm{S} \mathrm{cm}^{-1}$. In 1982 it ranged from 3.21 to $8.53 \mu \mathrm{S} \mathrm{cm}^{-1}$; the mean was $5.12 \mu \mathrm{S} \mathrm{cm}^{-1}$. For 1983, it ranged from 3.40 to $6.19 \mu \mathrm{S} \mathrm{cm}^{-1}$; the mean was $4.95 \mu \mathrm{S} \mathrm{cm}^{-1}$. The mean electrolytic conductivity of snow from Greenland was much lower than that of snow in Hanover, New Hampshire.

Concentrations of particulate matter in snow from Greenland ranged from 0.24 to $2.40 \mathrm{mg} \mathrm{kg}^{-1}$; the mean was $1.37 \mathrm{mg} \mathrm{kg}^{-1}$. The particulate matter was examined by scanning electron-microscopy. Several kinds of silicate minerals, spherules and unidentified organic particles were found. Spherules found in the snow samples are glass, $\mathrm{Fe}-$, Ti- and Ca-rich, and considered to be fly-ash particles from coal combustion.

\section{REFERENCES}

Koerner, R M and D A Fisher: 1982. Acid snow in the Canadian high Arctic. Nature 295(5845): 137-140

Kumai, M 1977 Electron microscope analysis of aerosols in snow and deep ice cores from Greenland. International Association of Scientific Hydrological Sciences Publication 118 (General Assembly of Grenoble 1975-Isotopes and Impurities in Snow and Ice): $341-350$

Kumai, M 1985 Acidity of snow and its reduction by alkaline aerosols. Annals of Glaciology 6: 92-94 